\title{
Mapping Students' Problem-Solving Skills in Physics Subject After Inquiry Learning at Class X SMAN 1 Prambanan
}

\author{
R. Z Putri, Jumadi, Ariswan, H. Kuswanto \\ Program Pascasarjana Pendidikan Fisika, Universitas Negeri Yogyakarta, Indonesia
}

Received: 5 January 2019. Accepted: 10 March 2019. Published: 1 July 2019

\begin{abstract}
Problem-solving skills is necessary to be mastered by students to help them in solving the problems of their daily life in the future. The purpose of this study was to map the student problem-solving skills after inquiry learning in Physics subject, impulse, and momentum in class X SMAN 1 Prambanan, Yogyakarta. Experimental research model with one-shot case study design was used in this study. Data collection was performed through essays at the end of the learning process. The results of the mapping show that students have different problem-solving skills levels at each stage. At the stage of problem identification, students were in a very good category. At the stage of planning the problem solution and problem-solving implementation, the students were in a good category, while in results evaluation, the students were in a fairly good category. The result of this study can contribute to giving the point of view to the teacher about students' problem-solving skills level based on the indicators as well as giving the additional information as a literature in the topic of students' problem-solving skills after inquiry learning.
\end{abstract}

\begin{abstract}
ABSTRAK
Keterampilan menyelesaikan masalah sangat diperlukan peserta didik, agar dapat menyelesaikan masalah dikehidupan nyata dan keperluan masa depan. Tujuan penelitian ini adalah untuk memetakan keterampilan menyelesaikan masalah peserta didik setelah pembelajaran inquiry pada pelajaran fisika materi impuls dan momentum di kelas X SMAN 1 Prambanan. Model penelitian eksperimen dengan desain one-shot case study digunakan dalam penelitian ini. Data dikumpulkan melalui tes essay diakhir pembelajaran. Hasil penelitian menunjukkan bahwa peserta didik memiliki tingkat keterampilan menyelesaikan masalah yang berbeda-beda pada setiap tahapan. Pada aspek mengidentifikasi masalah, peserta didik rata-rata berada pada kategori sangat baik. Aspek merencanakan penyelesaian dan melaksanakan perencanaan penyelesaian peserta didik rata-rata berada pada kategori baik, sedangkan pada mengecek kembali hasil, peserta didik rata-rata berada pada kategori cukup baik. Manfaat penelitian adalah untuk memberikan gambaran umum kepada guru tentang tingkat keterampilan penyelesaian masalah peserta didik sesuai dengan indikatornya, dan menambah referensi dalam penelitian keterampilan menyelesaikan masalah peserta didik setelah pembelajaran inquiry.
\end{abstract}

Keywords: Inquiry; Mapping; Problem-Solving Skills.

\section{INTRODUCTION}

Problem-solving skills are the skills that students need to have in the $21^{\text {st }}$ century. Wrahatnolo \& Munoto (2018) explained that the problem-solving skills are essential for students as a preparation for facing problems in real life in the future. As an effort to instill this skill, various innovative learning models by the method

*Correspondence Address:

Jalan Colombo Nomor 1, Karang Malang, Kec. Depok, Kabupaten Seleman, Daerah Istimewa Yogjakarta 55281- Indonesia E-mail: rahmiputriz09@gmail.com of student centers' learning can be applied. These models can help students in developing and building knowledge and skills. Mullin (2017) stated that the active learning approach could improve student learning outcomes and enhance the experience of students in the classroom.

Based on observations at school, the implementation of learning still mostly employs the model of direct instruction. However, the direct instruction model learning format often does not work well for some students in the class. Students who already understand the 
lesson will get bored quickly with the learning process, while students who do not understand will start to disturb other friends in the class. This learning model often fails to involve students in learning because students have insufficient skills to participate in learning (Bender, 2011). Based on this experience, with diverse groups of students, it is clear the direct instruction learning model needs to be modified as needed or can be replaced with other learning models that can increase various kinds of student activities in the classroom. It is because learning with different models can make it possible to choose the most effective model. There are many choices of learning models that can be applied in class. One learning model that is recommended for use in the 2013 curriculum is the inquiry learning model.

Inquiry learning encourages students into active learning activities and the teacher as a facilitator of the learning experience. Students can explore the contents of learning and acquire skills that are important in the learning process (Mullins, 2017). Lom (2012) explained that students would learn better if they do it themselves, compared to just listening to the explanation from the teacher. Based on the previous results of research, it indicates that inquiry learning is a strategy for gaining in-depth knowledge (Lombard \& Schneider, 2013), improving critical thinking skill and problem-solving skills (Alameddine \& Ahwal, 2016; Loyen \& Rikers, 2011), reducing stress levels of students, improve working memory of students (Bunterm et al. 2012) and communication (Loyen \& Rikers, 2011).

\section{$21^{\text {st }}$ Century Problem Solving Skills}

The problem-solving skills, according to Polya (2004), consist of understanding aspects of the problem, planning the problem solving, implementing problem-solving plans, and evaluating problem-solving implementation. When facing the problem, the ability of problem solving is different one to another student (Rahmawati et al. 2017). The most reasonable answer on this phenomena is, it could be due to the different problem-solving skill levels that students have.

In the 21st century learning, students are expected to have the ability to solve various types of problems including those that are not common/ rarely encountered, both in conventional and innovative ways, able to identify and ask significant questions that clarify various points of view and lead to better solutions
(AACTE, 2010). Jonassean (2011) states that the only objective of legitimate cognitive education in every educational context is problemsolving.

In the Physics subject, the problemsolving skills are used more in solving mathematical problems that are closely related to the ability of students to read and understand problems, showing the problems and designing the mathematical models, planning the mathematical model calculations, solving calculations from problems encountered, and translating solutions obtained (Wardani et al. 2018). Students who are unable to apply these steps are mostly have low learning outcomes.

\section{Learning Model Inquiry}

The teacher has the role of choosing the best learning model that can be used in class to help students learn actively (active learning). The active learning approach can improve student learning outcomes and enhance the experience in the classroom (Mullin, 2017). The 2013 curriculum provides several models to assist teachers in implementing active learning. The learning models suggested in the 2013 curriculum are inquiry-based learning models, discovery learning models, and project-based learning models (Putri \& Jumadi, 2017). One suitable learning model used in science lessons is the inquiry learning model, which leads to active learning (Loyen \& Rikers, 2011; Vat, 2010).

Some of the benefits of inquiry learning are: 1) can develop critical thinking skills, support in solving problems, understanding concepts from science material (Chiappetta \& Koballa, 2014); 2) help students to understand what is discussed in science and what scientists do (Pedaste \& Sarapu, 2011); 3) encourage students into active learning activities and the teacher as a facilitator of the learning experience; 4) help students acquire skills that are important in the learning process (Mullins, 2017); 5) teachers can prepare their students to learn through the questions that have been provided, which will motivate students to ask questions and to find the fact (Alameddine and Ahwal, 2016).

Chiappetta \& Koballa (2014) stated that inquiry could be carried out with the $5 \mathrm{E}$ stages, namely Engagement (attracting the attention of students to engage in learning), Exploration (students conduct investigations, be it collecting data, trying ideas, recording observations, and experiments, where students must be awa- 
re of patterns and relationships and raise various questions), Explanation (at this stage the teacher facilitates students by asking questions to encourage finding patterns, relationships to answer questions. At this stage, students need to answer with using their language), Elaboration (at this stage students are given the opportunity to apply the knowledge they have in different situations. Students work in groups or individually), Evaluation (at this stage, students demonstrate knowledge and understanding that they already have). Meanwhile, according to Dell 'Olio \& Donk (2007) stages of inquiry include: developing questions, generating hypotheses, developing experimental designs, collecting data, analyzing data, drawing conclusions, forming and broadening generalizations, and communicating results. Based on the explanation above, while in this study, the researcher modifies the inquiry stage in the following stages: (1) problem identification, (2) problem formulation, (3) hypothesis generation, (4) data collection, (5) data analysis, (6) concluding, and (7) communication. The purpose of this study is to map students' problemsolving skills after inquiry learning. The inquiry learning process carried out in this study was active learning. The teacher is in charge as a facilitator in the learning process. In addition to assessing students' problem-solving skills, the learning process that takes place is also explained in the discussion section.

\section{METHOD}

\section{Research Design}

This research was experimental, employing the one-shot case study design. The experiments were carried out without a comparison group and no test at the beginning of learning. The implementation of experiments in the form of inquiry model learning in class for two meetings. At the end of the lesson, the measurement of problem-solving skills was done by an essay test.

\section{Research Subject}

The subjects of this study consisted of 52 students in physics in class X SMA Negeri 1 Prambanan, Yogyakarta. 25 people in class $X$ IPA 1 and 27 people in class X IPA 2.

\section{Data Collection and Data Analysis}

Mapping of students' problem-solving skills was done after the inquiry learning process was carried out. The test given was an essay test consisting of 5 items. Students were given an answer sheet with a template that has been adjusted to the indicator of problemsolving skills based on Polya (2004), i.e. problem identification (known and asked), planning problem solving, problem-solving implementation, and evaluating results. It was made in order to measure the answers obtained from students.

Table 1. Student assessment rubric in Physics problem-solving skills

\begin{tabular}{|c|c|c|c|}
\hline $\begin{array}{l}\text { Problem-solving skills } \\
\text { indicators }\end{array}$ & Measured Aspects & Point & Assessment Rubric \\
\hline Problem identification & $\begin{array}{l}\text { Learners can write down } \\
\text { the known and asked ques- } \\
\text { tions. }\end{array}$ & $1<X \leq 5$ & $\begin{array}{l}\text { 1. Students only write } 1 \text { of } 2 \text { or } 3 \text { that are } \\
\text { known and do not write what is asked. } \\
\text { 2. Learners write in full the known but not } \\
\text { write the question. } \\
\text { 3. Learners write down entirely what is } \\
\text { known, and write } 1 \text { of } 2 \text { or } 3 \text { that are } \\
\text { asked. } \\
\text { 4. Learners write in full the known and } \\
\text { asked, but do not include the unit. } \\
\text { 5. Learners write in full the unknown and } \\
\text { asked along with the unit. }\end{array}$ \\
\hline Problem-solving planning & $\begin{array}{l}\text { Students can write a plan } \\
\text { that would be used in solv- } \\
\text { ing the given problem. }\end{array}$ & $1<X \leq 5$ & $\begin{array}{l}\text { 1. Learners write inappropriate equations } \\
\text { to solve problems. } \\
\text { 2. Students write the right equation to solve } \\
\text { the problem, but it is not perfect. } \\
\text { 3. Students write a complete equation, but } \\
\text { the sequence is still incorrect. } \\
\text { 4. Learners write the exact and complete } \\
\text { equation but need a little improvement. } \\
\text { 5. Learners write exact and complete equa- } \\
\text { tions, in the right and perfect order. }\end{array}$ \\
\hline $\begin{array}{l}\text { Problem-solving imple- } \\
\text { mentation }\end{array}$ & $\begin{array}{l}\text { Students can solve the } \\
\text { problems given following } \\
\text { the plan. }\end{array}$ & $1<X \leq 10$ & $\begin{array}{l}\text { 1. Students only write the equation, and it } \\
\text { is incorrect. }\end{array}$ \\
\hline
\end{tabular}




\begin{tabular}{|c|c|c|c|c|}
\hline & & & $\begin{array}{l}2 . \\
3 . \\
4 . \\
5 . \\
6 . \\
7 . \\
8 . \\
9 . \\
10 .\end{array}$ & $\begin{array}{l}\text { Students only rewrite the equation that } \\
\text { is used correctly. } \\
\text { Learners write only answers without } \\
\text { any stages of completion. } \\
\text { Students write down the equation used } \\
\text { with the correct answer. However, it is } \\
\text { not accompanied by stages of comple- } \\
\text { tion. } \\
\text { Students write answers with certain } \\
\text { stages, but the equation used is not } \\
\text { right, so the answers obtained are not } \\
\text { right. } \\
\text { Learners use the right equation. How- } \\
\text { ever, the completion stage is not per- } \\
\text { fect, so the results are incorrect. } \\
\text { Students use the correct equation and } \\
\text { write the answers with the correct and } \\
\text { complete stages. However, the final an- } \\
\text { swer is still not right. } \\
\text { Learners use the correct equation. The } \\
\text { answer is correct, but there are stages } \\
\text { of completion that are not written down } \\
\text { or are not sequential. } \\
\text { Learners write the right equation and } \\
\text { stages of completion correctly. The an- } \\
\text { swer is correct, but do not write down } \\
\text { the units of the results obtained. } \\
\text { Learners do perfectly. Correct equa- } \\
\text { tions, correct stages, correct answers } \\
\text { with units. }\end{array}$ \\
\hline Result Evaluation & $\begin{array}{l}\text { Students re-check the } \\
\text { results by writing down } \\
\text { the concept that has been } \\
\text { made and compares it. }\end{array}$ & $1<X \leq 5$ & $\begin{array}{l}1 . \\
2 . \\
3 . \\
4 . \\
5 .\end{array}$ & $\begin{array}{l}\text { Students re-checked, but it is not right. } \\
\text { Students only rewrite the answers ob- } \\
\text { tained from the implementation of the } \\
\text { plan. } \\
\text { Students write down in detail that needs } \\
\text { to be rechecked by mentioning the } \\
\text { quantities used, but did not explain oth- } \\
\text { er comparisons that can check answer. } \\
\text { Students re-checked by writing down } \\
\text { the amount used, other comparisons } \\
\text { that can be used in re-checking the re- } \\
\text { sults, but not quite right. } \\
\text { Students re-checked by writing down } \\
\text { the amount used, other comparisons } \\
\text { that can be used in re-checking the re- } \\
\text { sults, and include the results obtained } \\
\text { correctly. }\end{array}$ \\
\hline
\end{tabular}

The test was assessed using the assessment rubric, which can be seen in Table 1 .

Students who did not answer at several stages that have been given are given a zero value. The level of problem-solving skills in students can be observed by using the test result data obtained are then analyzed using the formula:

$$
P=\frac{n}{N} \times 100 \%
$$

Information:

$\mathrm{P} \quad=$ percentage of problem-solving skills

$\mathrm{n} \quad=$ number of scores achieved

$\mathrm{N} \quad=$ maximum number of scores

The results obtained are divided into each indi- cator, then interpreted in a qualitative range, as shown in Table 2.

Table 2. Percentage of problem-solving skills level of students

\begin{tabular}{ll}
\hline $76 \%-100 \%$ & $=$ very good \\
$51 \%-75 \%$ & $=$ good \\
$26 \%-50 \%$ & $=$ fairly good \\
$<25 \%$ & $=$ poor
\end{tabular}

In addition, the inquiry learning process based on observation during the learning process is explained in a descriptive qualitative manner. 


\section{RESULTS AND DISCUSSION}

In the implementation of inquiry learning that has been carried out, the learning process was carried out in several stages namely: problem identification, problem formulation, hypothesis generation, data collection, data analysis, concluding and communicating.

\section{Stage of Inquiry Learning}

\section{Problem Identification}

At this stage, the teacher acted as a facilitator, providing learning materials that can help students in understanding the problem. As for this stage, the teacher gave some pictures and videos. Students observed the video/animation that was displayed to understand the problem. Based on Doyan \& Sukmantara's (2014) research, using animation can make it easier for students to form concepts. Also, Iswatun et al. (2017) stated that through inquiry learning can improve observation skills.

\section{Problem Formulation}

Based on the animation/video learning that has been given by the teacher, students then wrote down the problem formulation. The formulation of the problem was written in the form of several questions. Written questions were questions that challenge students to think about solving them. Fauziyah (2015) explained that formulating a problem is a stage that will direct students towards questions/problems to be solved.

\section{Hypothesis Generation}

In generating hypotheses, students made short answers that can answer the questions they wrote. In making hypotheses, the teacher helped students by connecting images and videos that have been observed with the basic concepts of the material being taught. The teacher also provided another illustration by linking the concept of matter with what is around the environment of the students. Iswatun et al. (2017) stated that through this stage, students are trained to be able to formulate hypotheses. The stages of formulating this hypothesis are not obtained in Direct Instruction learning because the learning does not present a problem.

\section{Data Collection}

When collecting data, students were divided into several groups. The teacher fa- cilitated students to collect data with the help of questions that have been provided by the teacher. Students were given the freedom to search for learning resources in various forms. For example, from printed books, magazines, internet, and journals. The teacher supervised students to stay on the subject matter. Fauziyah (2015) explained that collecting data is part of a mental process that is needed by students in developing their intellectuals.

\section{Data Analysis}

Students who have been divided into groups were directed by the teacher to discuss groups and exchange opinions about the data they have collected. Sorting out what is right and what is wrong. Kurniawati et al. (2014) described the process of data analysis conducted in groups can motivate passive students to get involved in expressing their opinions. The need for habituation in inquiry learning helps students to succeed in learning. Besides, the role of the teacher in guiding students who have not been able to analyze the data obtained is critical (Iswatun et al. 2017).

\section{Concluding}

Students who had analyzed the data check the truth of the data collected, combining it into one final thought. After all group members agreed, a conclusion was made. It was also explained by Damayanti et al. (2013) that at this stage, students described the findings obtained based on the results of hypothesis testing.

\section{Communicating}

After conclusions were made, students presented their conclusions in front of classmates. Other students, gave opinions to other groups that are progressing. Teachers listened to what students say and justify/ improve if what is conveyed by students is still not quite right. Also, explained by Sirait (2012) that through inquiry learning, it can provide opportunities for students to be more willing to speak in front of the class.

In each inquiry learning process, the teacher guided students to be able to do every stage of learning. As for some challenges in the implementation of inquiry learning based on the implementation carried out as follows:

In the implementation of the stage of problem introduction to students, the teacher realizes that not all students can directly grasp the problem. The teacher must be able to use a 
variety of media and materials in conveying basic understanding or concepts so that students can follow the next stages of inquiry learning well.

The demand for students to be active in the learning process is a teacher's responsibility. The teacher is responsible in facilitating students; therefore, they can be active in the learning process. The different character of students has an impact in different learning patterns. The diverse learning motivations make it difficult for teachers to invite students to be active as a whole. It can be seen from the still students who chat during the learning process, are indifferent to the tasks given, and disturb other friends. Therefore, teachers need to have great attention in carrying out the learning process, including paying attention to the needs of all students; therefore, all students can learn well.

At the stage of formulating the problem, and making hypotheses, the teacher must be able to communicate well what problems the teacher wants so that students find out and understand. The teacher must be able to stimulate students about the material presented so that students feel interested in learning.

The need for more time than traditional learning sometimes makes teachers return to traditional learning. That was caused by the teacher's obligation in completing all chapter material in each semester. The teacher considers if inquiry learning can spend too much time which can reduce the teacher's time in completing other subject matter. It was also explained by Iswatun et al. (2017); that one of the obstacles in inquiry learning is the lack of time in completing the experiment.

In addition to the demands of more extended time, teachers must prepare teaching materials that can facilitate students to learn actively. It is a challenge for teachers. The teacher does not have time to prepare for these various things because they still have other activities outside of school.

Some ways that teachers can use to improve and deal with inquiry learning challenges are as follows: 1) teachers can use instructional media, assign tasks with different levels of difficulty and provide guidance according to the needs of students (Merrienboar, 2013) to deal with students' abilities different ones. 2) learning can take advantage of online / internet facilities (So, et al. 2012), blended learning (Sastradika, 2018) to help deal with the lack of time when learning inquiry. 3) teachers can develop problem-solving assessment rubrics that are appropriate for teachers and students to make it easier for students to implement strategies in solving problems (Halim et al. 2016). 4p) teachers can apply technology in learning to increase students' interest in learning, attitudes, and problem-solving activities (Hooshyar et al., 2015). In addition, teachers can use technology to help communicate well what problems the teacher wants; therefore, students find out and understand.

\section{Mapping the Problem-Solving Skills}

The results of the skills test to solve students' problems after learning the inquiry model are presented in Table 4.

Table 4. The results of the assessment on students' problem-solving skills in Physics subject

\begin{tabular}{llcc}
\hline Problem Solving Skill Indicators & \multicolumn{1}{c}{$\begin{array}{c}\text { Assessment } \\
\text { Criteria }\end{array}$} & $\begin{array}{c}\text { Student } \\
\text { Number }\end{array}$ & $\begin{array}{c}\text { Average of } \\
\text { Percentage }\end{array}$ \\
\hline Problem identification & Very Good & 49 & 95 \\
& Good & 1 & (Very Good) \\
& Fairly Good & 2 & \\
& Poor & 0 & \\
\hline Planning the problem solving & Very Good & 25 & 68.23 \\
& Good & 14 & (Good) \\
& Fairly Good & 10 & \\
& Poor & 3 & \\
\hline Problem-solving implementation & Very Good & 33 & 73.77 \\
& Good & 15 & $($ Good) \\
& Fairly Good & 8 & \\
& Poor & 8 & \\
\hline Result Evaluation & Very Good & 15 & 47.23 \\
& Good & 8 & (Fairly Good) \\
& Fairly Good & 8 & \\
\hline & Poor & 21 & \\
\hline
\end{tabular}


The average results of the mapping on students' problem-solving skills, based on indicators of problem-solving proposed by Polya (2004) can be seen in Figure 1.

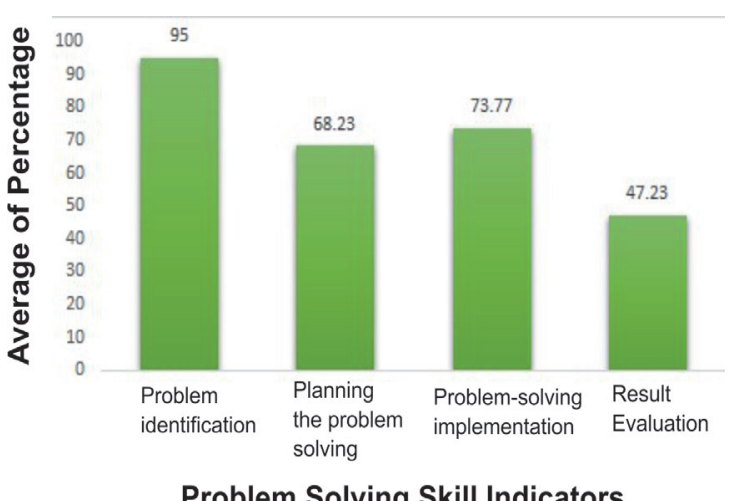

Figure 1. Results of mapping on students' problem-solving skills

Based on the results obtained from the data obtained, it can be seen that the aspects of identifying students' problems were in the very good category. At the stage of planning the problem, and implementing the plan, students as a whole are at a good level. While in evaluating the answers, students were at a fairly good level. Almost the same thing is also shown in the results of research conducted by Ubay \& Rosdiana (2018) which explained that students at the stages of identifying problems, designing solutions, collecting data, determining solutions, and rechecking results are in good criteria.

In the research conducted by researchers, students have sufficient value in the rechecking stage, while in research conducted by Ubay \& Rosdiana (2018) students have sufficient value in determining the solutions included in the stages of planning implementation. As in other studies, conducted by Halim et al. (2016), also explains that students, in general, have good grades in every aspect of problem-solving skills. However, it has a low value at the stage of detailing the problem.

The above shows that students, in general, have different levels of problem-solving skills at each stage. It can be caused by the level of knowledge and understanding in solving problems. Therefore, each teacher needs to identify their students' problem-solving skills so that they can give emphasis or appropriate treatment at each stage of learning.

As for the findings from the mapping of problem-solving skills that have been carried out as follows :

\section{Problem Identification}

At the stage of problem-solving students as a whole had a very good ability. It shows that students meet the ability to recognize problems. Irawan et al. (2016) stated that at the stage of identifying problems, students are required to be able to have an ability to understand the problem in-depth, ie, students can analyze information, patterns, or relationships that exist in the problem and then can link information this information to help in directing the method to be used in solving problems.

\section{Planning a Problem-Solving}

In planning a problem-solving, it can be seen the diversity of students' abilities in planning problem-solving. Students had different abilities in interpreting problems in the form of planning. There were still students who have not been able to do appropriate planning, identifying that students have not understood correctly the concept of the problem they found. Even so, the average ability of students is at a good level. This is also supported by research conducted by Ubay \& Rosdiana (2018) who also found that students were in a good category for planning problem-solving.

\section{Problem-Solving Implementation}

The results of implementing the plan have a higher value than planning problem-solving. It shows another reason for the value of planning a low problem solving that is that students might already knew the concept of the problem but were unable to describe it in the form of planning. In the implementation of the completion of students as a whole were in the level of good categories. It is consistent with the research of Halim et al. (2016) which explains students have been able to solve the problems given, even with different levels of ability. It is also due to the stages of completion; in general, there has been at every solution of physical problems.

\section{Results Evaluation}

On re-checking answers, students were only in the good enough category. It identifid that students might have a lack of ability to re-check what they have done to make them confused. This situation is called disequilibrium (unbalanced). In the research conducted by Safrida et al. (2015) explained that in checking the results of the settlement there were students who experienced disequalibrium, which looked confused and was just silent to determine the steps to re-examine the answers they got. 
As for some cases of students in solving physics problems can be seen in Figure 2 and Figure 3.

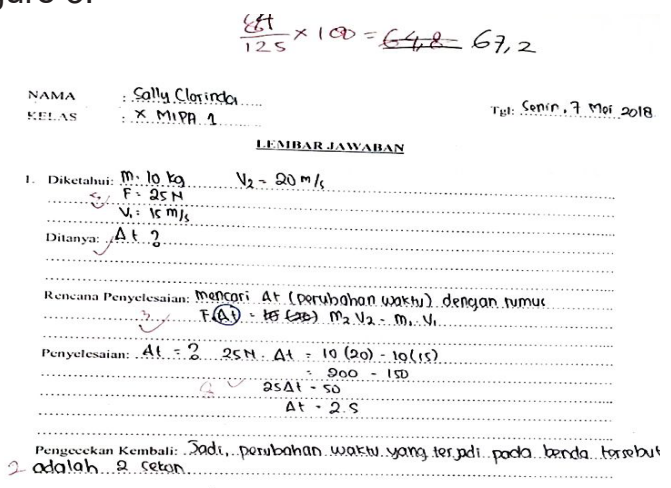

Figure 2. Results of student answer sheets

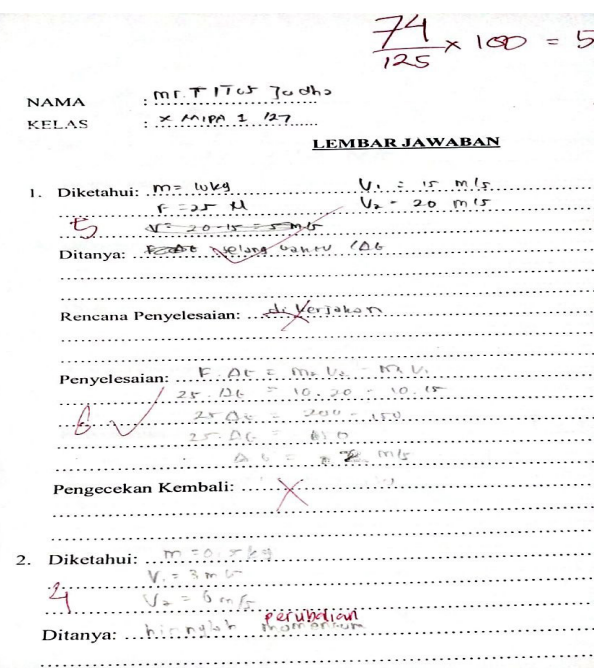

Figure 3. Results of student answer sheets

Based on these results it is known that in the inquiry teaching and learning process that aims to improve students' physics problem-solving skills, the teacher must emphasize learning on indicators of problem-solving planning, problem-solving implementation, and evaluation. Also, it is necessary to habituate students to do activities to solve problems. Instead of teaching students all subject matter that needs to be had, students should be allowed to solve new problems themselves to be able to improve their problem-solving skills through various experiences and empirical investigations (Jonassen, 2011).

\section{CONCLUSION}

The results of the mapping on students' problem-solving skills after inquiry, it can be concluded that students had different levels of problem-solving skills at each stage. The re- sults show that in the aspect of problem identification, students on average were in the very good category. In problem-solving planning, students on average were in a good category. In the stages of problem-solving implementation, the average students were in a good category, while in evaluation, the average students were in the fairly good category. In inquiry, these results can be better with an emphasis on aspects of planning implementation and evaluation. Some of these aspects can be improved through the inquiry stage on the condition that the teacher can understand the needs of students and can handle obstacles during the inquiry learning process. The existence of habituation in the use of inquiry can help teachers and students get used to the stages in the learning process in an inquiry. Further research needs to be done to find out in-depth the causes of the evaluation indicators of answers to the problem-solving skills that are still quite low in students. The lack of understanding of students in evaluation can also be caused by other factors that need to be investigated.

\section{ACKNOWLEDGMENT}

Thanks to the Directorate of Research and Community Service, Directorate General of Research Strengthening and Development, the Ministry of Research, Technology and Higher Education who have funded this research according to the contract implementation of research number: 080/SP2H/LT/DRPM/2019.

\section{REFERENCES}

AACTE. (2010). 21 ${ }^{\text {st }}$ Century Knowledge and Skills in Educator Preparation. United State of America: Pearson.

Alameddine, M. M., \& Ahwal, H. W. (2016). Inquiry Based Teaching in Literature Classrooms. Procedia - Social and Behavioral Sciences 232: 332 - 337. http://dx.doi.org/10.1016/j. sbspro.2016.10.031.

Bender, W.N. (2011). Differentiated Instruction and Response to Intervention in Mathematics. In L. Laud (Ed.), Differentiated Instruction in Literacy, Math, \& Science (pp.57-84). United State of America, USE : Corwin, A Sage Company.

Bunterm, T., Wattanathorn, J., Vangpoomyai, P., \& Muchimapura, S. (2012). Impact of open inquiry in science education on working memory, saliva cortisol and problem solving skill. Procedia - Social and Behavioral Sciences 46: 5387 - 5391. https://doi.org/10.1016/j. sbspro.2012.06.444. 
Chiappetta, E. L., \& Koballa, T. R. (2014). Science Instruction in the Middle and Secondary Schools. New York: Macmillan Publishing.

Damayanti, D. S., Ngazizah, N., Setyadi K. E. (2013). Pengembangan Lembar Kerja Siswa (LKS) dengan Pendekatan Inkuiri Terbimbing untuk Mengoptimalkan Kemampuan Berpikir Kritis Peserta Didik pada Materi Listrik Dinamis SMA Negeri 3 Purworejo Kelas $X$ Tahun Pelajaran 2012/2013. Radiasi, 3(1): 58-62.

Dell'Olio, J.M., \& Donk, T. (2007). Model of Teaching Connecting Student Learning With Standards. United State of Amerika: Sage Publications.

Doyan, A., \& Sukmantara, I. K. Y. (2014). Pengembangan Web Internet Fisika untuk Meningkatkan Penguasaan Konsep dan Kemampuan Pemecahan Masalah Siswa SMK. Jurnal Pendidikan Fisika Indonesia, 10(2):117-127. http://dx.doi.org/10.15294/jpfi.v10i2.3348.

Fauziyah, D. (2015). Penerapan Strategi Pembelajaran Inquiry pada Mata Pelajaran Ekonomi Pokok Bahasan Pasar. Proceding Seminar Nasional Pendidikan Ekonomi FE UNY “ Profesionalisme Pendidikan dalam Dinamika Kurikulum Pendidikan di Indonesia pada Era MEA". Skripsi. Yogyakarta: Program Studi Pendidikan Ekonomi UNY.

Halim, A, Yusrizal, Susanna, \& Tarmizi. (2016). An analysis of students' skill in applying the problem solving strategy to the physics problem settlement in facing AEC as global competition. Jurnal Pendidikan IPA Indonesia, 5(1):15. https://doi.org/10.15294/jpii.v5i1.5782

Hooshyar D., Ahmad R.B., Yousefi M., Fathi M. \& Horng S. J. (2015). Applyingan Online Gamebased Formative Assessment in a Flowchart-based Intelligent Tutoring System for Improving Problem-solving skills, Computers \& Education, http://dx.doi.org/10.1016/j. compedu.2015.10.013.

Irawan, I. P. E., Suharta, I. G. P., Suparta. (2016). Faktor-faktor yang Mempengaruhi Kemampuan Pemecahan Masalah Matematika: Pengetahuan Awal, Apresiasi Matematika, dan Kecerdasan Logis Matematika. Proceding Seminar Nasional MIPA. ISBN 978-6026428-00-4.

Iswatun, I., Mosik, M., Subali, B. (2017). Penerapan Model Pembelajaran Inkuiri terbimbing untuk Meningkatkan KPS dan Hasil Belajar Siswa SMP Kelas VIII. Jurnal Inovasi Pendidikan IPA, 3(2): 150-160. http://dx.doi. org/10.21831/jipi.v3i2.14871.

Jonassen, D. H.(2011). Learning to solve problems: a handbook for designing Problem-solving Learning Environments. New York: Routledge.

Kurniawati, I. D., Wartono., \& Diantoro, M. (2014). Pengaruh Pembelajaran Inkuiri terbimbing integrasi peer instruction terhadap Penguasaan Konsep dan Kemampuan Berpikir Kritis
Siswa. Jurnal Pendidikan Fisika Indonesia, 10: 36-46. http://dx.doi.org/10.15294/jpfi. v10i1.3049.

Lom, B. (2012). Classroom activities: Simple strategies to incorporate student centered activities within undergraduate science lectures. Journal of Undergraduate Neuroscience Education, 11(1): A64-A71.

Lombard, F.E \& Schneider, D. E. (2013). Good student questions in inquiry learning, Journal of Biological Education, 47(3): 166-174, http:// dx.doi.org/10.1080/00219266.2013.821749.

Mullins, M. H. (2017). Actively Teaching Research Methods with a Process Oriented Guided Inquiry Learning Approach, Journal of Teaching in Social Wor, 37(4): 309-321, http://dx.doi. org/10.1080/08841233.2017.1347122.

Loyen, S. M.M., \& Rikers, R. M. J. (2011). Instruction Based on Inquiry. Handbook of Research on Learning and Instruction. New York: Routledge.

Merrienboar, J.J.G. (2013). Perspectives on problem solving and instruction. Computers \& Education. 64: 153-160. http://dx.doi.org/10.1016/j. compedu.2012.11.025.

Pedaste, M., \& Sarapuu, T. (2012). Design Principles for support in developing students' transformative inquiry skills in Web-based learning environments. Interactive Learning Environment. 22(3), 309-325, http://dx.doi.org/10.10 80/10494820.2011.654346.

Polya, G. (2004). How to solve it. A new aspect of mathematical method with a new foreward by John H. Conway. United State of America: Princeton Science Library.

Putri, R.F., \& Jumadi, J. (2017). Kemampuan Guru Fisika dalam Menerapkan Model-Model Pembelajaran pada Kurikulum 2013 serta Kendala-kendala yang Dihadapi. Jurnal Inovasi Pendidikan IPA, 3 (2): 201-211. http:// dx.doi.org/10.21831/jipi.v3i2.8636.

Rahmawati, Rustaman, N. Y., Hamidah, I., \& Rusdiana, D. (2017). The Use of Classroom Assessment to Explore Problem Solving Skills Based on Pre-Service Teachers' Cognitive Style Dimension in Basic Physics Course. IOP Conf. Series: Journal of Physics: Conf. Series, 812(1). http://dx.doi.org/10.1088/17426596/812/1/012047.

Safrida, L. N., Susant,\& Kurniati, D. (2015) Analisis Proses Berpikir Siswa Dalam Pemecahan Masalah Terbuka Berbasis Polya Sub Pokok Bahasan Tabung Kelas IX SMP Negeri 7 Jember. Kadikma, 6 (1): 25-38.

Sastradika, D. (2018). Pengembangan SSP Fisika Model Guided Inquiry Berbantuan e-learning untuk Meningkatkan Literasi Sains dan Berpikir Kreatif Siswa SMA, (Unpublished Magister thesis). Program Pasca Sarjana, UNY, Yogyakarta.

Sirait, R. (2012). Pengaruh Model Pembelajaran Inquiry Training terhadap Hasil Belajar Siswa 
pada Materi Pokok Usaha dan Energi Kelas VIII MTS N-3 Medan. Jurnal Pendidikan Fisika, 1(1): 21-26. P-ISSN 2252-732X.

So, W. W., Cheng, M. M., Kong, S., Ching, N F. (2012). View of Primary Science Teachers Towards the Use of Online Resources to Support the Implementation of Inquiry, Education 3-13: International Journal of Primary, Elementary and Early Years Education, 42(4), 386-401, http://dx.doi.org/10.1080/03 004279.2012 .710640 .

Ubay, A. L., \& Rosdiana, L. (2018). Keterampilan Pemecahan Masalah Siswa Kelas VIII SMP. Pensa E-Jurnal, 6(2):376-380.

Vat, K. H. (2010). Developing Student e-Portofolios for Outcoms-Based Assessment in Personalized Instruction. In Y. Kats (Ed.), Learning
Management Systems Technologies and Software Solutions for Online Teaching: Tools and Implementations (pp. 259-290). New york, Hershey: Information Science Reference.

Wardani, D. S., Kirana, T., \& Ibrahim, M. (2018). The Development of Student's Activity Sheets (SAS) Based on Multiple Intelligences and Problem-solving skills Using Simple Science Tools. IOP Conf. Series: Journal of Physics: Conf. Series 947(1). http://dx.doi. org/10.1088/1742-6596/947/1/012047.

Wrahatnolo, T., \& Munoto. (2018). 21st centuries skill implication on educational system. IOP Conf. Series: Materials Science and Engineering, 296(1). http://dx.doi.org/10.1088/1757899X/296/1/012036. 